Article

\title{
Positive Discrimination Policies and Indigenous-Based ECEC Services in Bogota, Colombia
}

\author{
Carmen María Sanchez Caro $\mathbb{D}$ \\ Centre de Recherche Interuniversitaire Expérience Ressources Culturelles Éducation-EXPERICE, \\ Université Paris 13, 93430 Villetaneuse, France; carmen.sanchezcaro@edu.univ-paris13.fr
}

Received: 30 October 2018; Accepted: 25 January 2019; Published: 28 January 2019

\begin{abstract}
This article aims to present a few tensions and contradictions when implementing children's rights using the case of three Casas de Pensamiento Indígena (CPI) - indigenous childcare services—in Bogotá. It questions global policies and local interpretations of early childhood education. Its main purpose is to find insights on what it means to attend to young children from minority groups. Could early childhood education and care (ECEC) services be reduced to ethnic backgrounds? In the struggle to deal with global, local, and community discourses, policy makers see positive discrimination not only as a way to justify their actions and their policies but also as a way to respond to the question of equity and diversity, regardless of equality. Therefore, this article highlights this discussion on positive discrimination as a way to intensify social inequality or reproduce inequalities at another level with a different name. Rancière's dissertation on politics (Rancière 1998) and on the different meanings of politics and politique is used to understand the subtle relationship between equity and diversity. Considering all of this, it was decided to do fieldwork to comprehend the daily lives of CPI settings and the complexity of their formalization/institutionalization. The study highlights how CPI both differs from and is part of conventional services, and how indigenous caregivers and children face an institutional script that asks them to perform indigenism.
\end{abstract}

Keywords: performativity; indigenous children; ECEC services; institution scripts; early childhood policies; children's participation

\section{Introduction}

Bottom-up policies or grounded policies seem to be the focus of many discourses on implementing policies and children's rights approaches (Liebel 2012; Vandenhole 2012). This article aims to present the tensions and contradictions when implementing children's rights by introducing the case of three Casas de Pensamiento Indígena (CPI) — indigenous ${ }^{1}$ childcare services—in Bogotá, which brings up the question about global policies and local interpretations of early childhood education. This article is part of the author's doctoral dissertation, which aims to outline the institutionalization of CPIs in Bogotá. Its main purpose is to shed light on what it means to attend to young children from minority groups. Could early childhood education and care (ECEC) services be reduced to ethnic backgrounds? The study highlights how CPIs both differ from and are part of conventional services, which often leads to the question of "minority directions in the majority world" (Dahlberg et al. 1999; Vandenbroeck 2004). This analysis also questions the existing global and local ideas about ECEC

1 The term indigenas has been translated to indigenous, to keep the terms used by the research actors. 
services and their assumptions on the implementation of these services and young children's rights in practice (Boyden 1997; Mannion 2007).

Early childhood education is underscored by two trends. First is the welfare approach, which is centered on nutrition, care, and hygiene. These are viewed as the most important aspects related to childcare. Second is the pedagogical approach, which is grounded on the idea that children need to get a head start on their educational processes in order to be better prepared for when they attend school. These two trends in Latin American countries are unfortunately related to the social class of children ${ }^{2}$. Thus, welfare models are most widespread in public institutions that care for children in precarious areas or what Rosemberg (2010) in the Brazilian case or Rupin (2014) in the Chilean ECEC system define as the dilemma of poor education for poor communities. In other words, vulnerable communities require an education that tends to basic needs and builds everyday habits, whereas education for middle and upper classes is able to singularly focus on preparing children for school because the aspects related to care are satisfied by the family. This highlights the ambiguous nature of the interpretation of equity when it comes to children's rights. Colombia's history of early childhood policies is representative of these two perspectives.

The question becomes more complex when discussing indigenous children's rights because minority group policies have to be taken into account. The last census from the Departamento Administrativo Nacional de Estadísticas (DANE) reported a population of more than 45 million Colombians, where less than four million identified themselves as indigenous ${ }^{3}$. Yet, " 87 indigenous ethnic groups" were counted on the 2005 Census (DANE 2007). As a result of this demographic, Colombian policies related to indigenous communities are formulated based on "statistical information produced with an ethnic focus" that recognizes the existence of these groups (DANE 2007). Therefore, indigenous policies in general have always been formulated from a differential approach.

In fact, the Conpes 109-the first public policy for early childhood-in the hopes of providing young children with better ECEC services, was based on both focus and universalization: "We cannot universalize if we do not focus on the most vulnerable (...) we must focus attention to children and families at risk ( ... from extreme poverty or from belonging to groups or families in vulnerable situations" (Presidencia de la Republica 2007). Later, in 2016, early childhood policies-Cero a Siempre (2015) — focused on the political debate around equity, diversity, and quality following the global debate on ECEC services (Rayna 2010). As a matter of fact, recent documents released by Mesa de diversidad y enfoque diferencial (the diversity and differential approach board) focused on pertinencia cultural (cultural relevance) as a criterion to justify indigenous or minority group ECEC services (Comisión Intersectorial de Primera Infancia 2014) nationally labeled as Situado + Etnico.

Indeed, these early childhood policies are based on the principle that positive discrimination or a differential approach guarantees equity. In the struggle to deal with global, local, and community discourse, policy makers see positive discrimination not only as a way to justify their actions and their policies but also as a way to respond to the questions of equity and diversity, regardless of equality 4 . The result of this approach is the development of early childhood services as an industry and the institutionalization of community-based ECEC services such as CPIs (Molina and Baron 2011) and many others (Comisión Intersectorial de Primera Infancia 2014). As Torrado et al. (2017) highlighted, it is really difficult to know the services offered in the country, as the majority of children up to four years old stay in informal community and family-based arrangements. The implementation of Cero $a$ siempre has been a challenge to understand and build a more systematic image of what ECEC services

2 Colombia is one of the most populated and urbanized countries in Latin America. DANE's last census points out a population of more than 45 million people where almost $80 \%$ live in city areas (DANE 2018) stratified in six different socio-economical classes.

3 An ethnic identification variable has been included in the 2005 Census "that accurately captures the ethnic population and thus allows its characterization by crossing it with other variables studied" (DANE 2007).

4 Equity here is understood as the principle that guarantees equal access to each one depending on their need and context; different from equality, which is understood as giving the same opportunities to all, regardless of their context or needs. 
in Colombia are. The CPIs in Bogota define on city's policy text as services to "allow indigenous young children to learn, to reappropriate, to preserve their culture based on the specific and authentic practices of their community" (Bogota 2010, p. 20). Between 2007 and 2017, more than ten CPIs were recognized as formal services.

Therefore, this article highlights this discussion on positive discrimination and how it intensifies social inequality or at least reproduces inequalities at another level with a different name. We theorize using Rancière's dissertation on politics (Rancière 1998) and on the different meanings of politics and politique to understand the subtle relationship between equity and diversity. To consider indigenous community-based models in relation to other models of childcare settings and their impact on early childhood education policies brings forward the cultural and ethical dimensions. What is the real difference between CPI and conventional ECEC services? What has been pointed out by Deleuze (1968) or García Canclini (2004) as a discourse of difference? How "indigenous" ECEC services become so in everyday life depends on the discourse to define them as different.

\section{Positive Discrimination}

Positive discrimination policies are public policies that recognize particular rights in particular groups in a specific context. They are part of what is usually considered multicultural policies or differential policy-making approaches (Wieviorka 2004). This means that gender, race, or ethnic criteria are used to define how governments ought to guarantee people's rights (in this case, to assure young children's access to ECEC services in indigenous communities in Bogotá). The term and existence of "minority groups" or "marginalized communities" weakens the notion of social justice and equality and challenges for a democratic society (Velasco and Carlos 2007, p. 142). However, this set of policies does not target only cultural or identity issues. In practice, it belongs to a larger socio-political project that deals with diversity and equity. The main focus is to attend to minority groups or marginalized groups to create some sort of relief ${ }^{5}$ from what has been or is being done to them.

However, this positive discrimination-or affirmative action-has been largely criticized. For example, Giovanni Sartori argues that affirmative action continues to be a discriminatory practice, as "discrimination consists of unfairly favoring or disfavoring groups of people based on matters which are beyond their merits and abilities" (Sartori 2005, p. 51). Dworkin points out that these actions can be dangerous when they become a habit: "What begins in a localized and temporary way ends up becoming a permanent and extensive way of proceeding (and which is also internalized by the beneficiaries as acquired rights), thus contravening its initial reason, which was none other than the overcoming of all kinds of discrimination" (Velasco and Carlos 2007, p. 145). An example of these might be Gomez Gomez's (2015) study on indigenous and ladino peoples' interactions and how their rights and places are apprehended and contracted.

Nonetheless, both sides of this argument agree that these practices are based on a discriminatory principle. The treatment given to a certain group is only made by pointing this group out as different from the whole. As Rancière points out, "To designate the opposition is to constitute the place of a polemical division to affirm the non-place of any equal distribution" (Rancière 1998, p. 69). Understood in this article as the action of tracing the differences between indigenous children and other children, this discourse on difference means arguing that equality is not a possibility, as diversity is already shaped by difference. This brings us to the subject of this article: could indigenous ECEC services based on a positive discrimination policy guarantee equity and quality access to indigenous communities? If so, at what cost? What does this mean to indigenous children and their caregivers to be labeled as "indigenous" at an ECEC service? The next part discusses how this legal action creates everyday lives for children and their indigenous caregivers that are embedded in a constant

5 This term is used here as part of a resilience process that has been part of indigenous national policies and state's agreements for a long history of multicultural policies (see Gomez Gomez 2015). 
performativity of indigenous and authenticity. For the purpose of this article, performativity is understood as a contingent and constant production of meaning. Enacting what a category is ought to be, such as "What we take to be an 'internal' feature of ourselves is one that we anticipate and produce through certain bodily acts, at an extreme, a hallucinatory effect of naturalized gestures" (Butler 2011, p. XV). Does being indigenous constitute an institutionalized performance or is this "natural fact" constructed discursively by bodily actions that create and perform such a category? Do CPIs exist as an ethnic physical and cultural space to perform and institutionalize the indigenous being?

\section{Materials and Methods}

Through an exploration of policy documents from Colombia and Bogotá, an ECEC services field was built to understand Bogotá's ECEC system and its existing offer to guarantee education and care for young children. To summarize, Colombia's policies define three different models of ECECs shown in the state's policies and texts as "social and pedagogical spaces" where children "learn to live together, to know, love, and respect others; where they interiorize basic norms of living together and the recognition of others, of the particularity and diversity and everything that happens around them." These models are considered scenarios of "multiple and diverse experiences and interactions, specifically designed for early childhood. From that perspective, they distinguish themselves by their openness and appreciation of their social context and their contribution to it, from its own way of understanding society and the early childhood care for girls and boys" (Comisión Intersectorial de Primera Infancia 2014, p. 20). Thus, models are ways of organizing the national ECEC system to meet the different needs of families according to their choices, their desires, and their contexts. Both national systems and Bogota's ECEC system have a wide range of nuances within these models from private to public services, including hybrid services, which are mostly run by foundations. When focusing on Bogota, the city has a vast panorama of formalized to community-based services from collective to family-centered solutions. Some of them are recognized by law ${ }^{6}$, while the rest remain recognized by families and communities only. Considering all of this, it was decided to do significant fieldwork to analyze the daily lives of different ECEC settings in the city, as well as to better understand CPI settings and their formalization/institutionalization.

As a whole, CPI services are one of the many solutions for childhood education and care. They exist in the context of "inclusive education with a 'differential approach' that allows equity of opportunity, without discrimination ( ... ) advancing processes of family and community strengthening" (SDIS 2012, p. 11) and underline the fact that they are services that adapt to the "characteristics of ethnic groups" and "populations with specific vulnerabilities" (2012, p. 12). According to Suárez (2014), CPIs are not the result of the city's Plan de Dessarollo, but rather a response to the demands made by the city's various indigenous communities in recent years-for example, the opening of the first CPI in Bogotá in 2009 (Molina and Baron 2011; Suárez 2014). The first communities to organize an indigenous ECEC service were the forbearers of the CPI. The project was "to enable indigenous children to learn, recover, and preserve their culture based on the specific and ancestral practices of their community" (Bogota 2010). On this subject are several thesis and dissertations written about CPIs in Bogotá (Quevedo 2012; Reyes 2018). In particular, Molina and Baron (2011) address the experiences of two CPIs and the construction of their educational projects and curriculum. An overview of the CPI shows an ECEC service for children from ages one to five years old belonging to a particular indigenous community. Some are open to every child living in the area. At the moment, ten CPI services are recognized, organized, and managed by eight different indigenous communities located in different areas around the city, mostly in the vulnerable ones. Each CPI has a different internal organization and a different way of conceiving, for example, how the

6 In Bogota ECEC services can choose whether if they are recognized by the SDIS, the Secretaria de Education or by the Ministerio de educacion itself. 
professional group should be constituted [only Early Childhood Indigenous Caregivers (IC) and Early Childhood Professionals (ECP) or IC from different communities].

One of the main methodological questions was choosing as field only institutions labeled CPI as a main criterion, which underlines what other researchers have discussed as the "difficulties associated with visibility" for indigenous groups (Kaomea 2003, 2005; Brayboy and Jones 2003). In other words, the data were only collected on recognized indigenous ECEC services. It must be noted that access to these particular settings is not always granted and is very complex for two reasons, the first being public official term limits and the second being the fact that authorizations must come from both public officials and the indigenous community's governance corps ${ }^{7}$. Therefore, the communities and the public officials were approached at the same time to guarantee the agreement of the communities, specifically the IC. The communities of the three CPIs agreed to be observed in their daily routines and to discuss the videos recorded and analyze them further with the researcher. Thus, this particular context allowed us to study a set of CPIs that reflected distinct situations (Table 1).

Table 1. List of the field and their particularities.

\begin{tabular}{|c|c|c|}
\hline CASA A & CASA B & CASA C \\
\hline Less than a year working & New one & Open more than 6 years ago \\
\hline $\begin{array}{l}\text { Has been organized by a private } \\
\text { foundation }\end{array}$ & $\begin{array}{l}\text { Is a Bogota's city project to } \\
\text { respond to an indigenous } \\
\text { community petition }\end{array}$ & Community based project \\
\hline $\begin{array}{l}\text { Has been given a room inside a } \\
\text { conventional early childhood education } \\
\text { and care (ECEC) service run by the } \\
\text { foundation }\end{array}$ & $\begin{array}{l}\text { Built on a recover municipal } \\
\text { building }\end{array}$ & $\begin{array}{l}\text { Has lost his initial physical } \\
\text { space and is actually inside a } \\
\text { city's official's ECEC service }\end{array}$ \\
\hline $\begin{array}{l}\text { Only Early Childhood Indigenous } \\
\text { Caregivers (IC) from the community, but } \\
\text { with an Early Childhood Professionals } \\
\text { (ECP) coordinator, that holds an idea of } \\
\text { what they ought to be and do as Casas de } \\
\text { Pensamiento Indigena (CPI) }\end{array}$ & $\begin{array}{l}\text { Different communities IC and } \\
\text { some ECP }\end{array}$ & $\begin{array}{l}\text { Only IC from the community } \\
\text { but sharing a room and a } \\
\text { planning with ECP }\end{array}$ \\
\hline
\end{tabular}

A multi-method approach was used to gather information (Table 2). Fieldwork was conducted for two weeks in each institution to observe-via video-their daily routines and practices in a class of children two to three years old. This was followed by individual interviews with parents and professionals at each institution and conversations with policy-makers and public officials about the ECEC services in Bogotá. The main goal was to understand the discourse of indigenous-oriented ECEC services based on the positive discrimination approach (Glazer 1975; Velasco and Carlos 2007). The empirical data were interpreted with the help of ECEC monographies by focusing the analysis of the dialogues and the situations occurring during the time of the observations in these ECEC services.

Table 2. List of the field and the data collected.

\begin{tabular}{ccccc}
\hline Institution & Observation & Focus Observation & $\begin{array}{c}\text { Interview with } \\
\text { Professionals }\end{array}$ & $\begin{array}{c}\text { Interview with } \\
\text { Parents }\end{array}$ \\
\hline CasaA & 3 days & 4 days & 1 interview 2IC & 3 Interviews \\
CasaB & 3 days & 4 days & 2 interviews 2 IC & 4 interviews \\
CasaC & 3 days & 4 days & 2 interview 1IC 1 Taita & 4 interviews \\
\hline
\end{tabular}

7 Bogotá has more than 17 different indigenous communities living in the city, and each of them has its own political governance institutions and agreements with the city's government. 
This study faces two important ethical issues. The first concerns the specifics of the video observation as a method of study, which means asking participants for their authorization and fulfilling the requirement of anonymity. However, obtaining children's authorization to follow them, was more difficult, as it was given through the relationships built with them during the fieldwork. Nevertheless, parents, professionals, and caregivers formally gave their authorizations. The second ethical question is the reliability and validity of the findings, as video observation only captures one image and not the whole environment. It is difficult to say whether the situation was captured objectively, as the researcher chose which parts to observe, and the data in this study were subject to free interpretations made by the researcher. However, the researcher's standpoint does not undermine the value of the study, as the selection of the data was justified and the conclusions were supported by the material produced by fieldwork (Flyvbjerg 2006). As mentioned before, the three CPIs studied are not representative of all CPIs; they are cases that help shed light on some questions about the existing CPI services in Bogotá.

\section{Results}

Policies and legal actions on behalf of CPIs show the value of the existence of different ECEC services in the city. In the city's official texts and in the indigenous curriculum (Bogota 2010, p. 14), we find the role of the Secretaria Distrital de Integracion Social (SDIS) ${ }^{10}$ in the formalization of CPI projects in Bogotá. In this document, CPIs are institutions that guarantee both "civil rights" and "specific rights". For example, cultural identity is defined as a "fundamental right" where "culture is constituted as a fundamental element to be able to be, in their case, to be indigenous" (Molina and Baron 2011). The purpose of a CPI is that children feel like they belong to an indigenous culture and have the opportunity to be educated according to the customs and ideologies specific to their cultural background (Contcepi 2012). This part presents the results of the analysis from two angles-the professional posture and the idea of being indigenous. These two aspects rely on what the CPI ought to be or what is supposed to be their main purpose. In the first part, indigenous caregiver's relations to ECEC services scripts is analyzed to see how they are adapting to the "habit" of being early childhood education practitioners. A script is understood here as a "representation of the world"(Vinegar, in Gutierrez et al. 1995) "to describe the construct that accounts for appropriate participation in routinized interactions" (Schank and Ableson, in Gutierrez et al. 1995). Examples of being indigenous as a performative category are described at the end of this section, with special emphasis on the idea that being indigenous is an institutionalized category that demonstrates how professionals and children should be and act.

\subsection{Professionals' Posture versus Institution Scripts}

One of the main findings in this research is the relationship between the institutions and the indigenous caregivers. Caregivers have no diplomas and their qualifications to be ECP are given by the simple fact that they are a part of certain indigenous or minority group. They are the bridge, or in other words, the "primary agents of conditioning" (Elias 1994, p. 119), between the institutional scripts and childcare and education, as well as between global discourses of early childhood education and local practices and interpretations of childhood. In CasaA, for example, most of the time, other professionals or the pedagogical coordinator explained to the indigenous caregivers how to organize the day and how to set up an activity, such as "Give them the light green papers and that's it, for the rest ... you will see as you will, for the material, I mean". Sometimes, the pedagogical coordinator explained to

9 Respectful term to address older men who carry the wisdom of the community. Sometimes they are also the communities' political leaders.

8 Parents' and professionals' interviews are mentioned in this article but analyzed in the author's dissertation.

10 SDIS is the district entity in charge of formulating the policies related to social integration, especially to those in greater poverty and vulnerability. 
indigenous caregivers that it is normal for indigenous children not to follow activities, as "All this is because it is not usual, they are not used to it ... you take them, you bring them ... Like you too, you are getting them yourselves, the habit of ... then while you take the habit ... " (Sanchez Caro 2016) Both adults and children from the community are in the process of getting used to this type of education. This kind of dialogue brings to light the idea that the ECP coordinator's work is to assure that indigenous caregivers are adjusting well to the global function of the ECEC center. In other words, she has to teach them how to be an ECEC teacher or caregiver, how to organize, plan, and schedule daily activities, and how to adjust to the script.

The idea of routine and how it is assimilated in this dialogue is interesting. Routine is a central part of the institutional script in ECEC services, and indigenous adults and children should incorporate it in order to be part of the institution. In another dialogue, the ECP explained to indigenous caregivers the importance of naptime after lunch. For the caregivers, sometimes these routines or habits are complicated to follow, as children might sleep during different moments of the day. However, as the ECP pointed out, "They shouldn't be sleeping [right now], because now [in the morning] it's time to do the activity". At the end of the conversation, the ECP explained to them the importance of establishing a nap routine because it "is a way for [the professionals] to rest ... " She provided them with some strategies to assure that the children slept at that particular time, such as "Don't finish the nap until they're all asleep. So, for example, take blankets, then put them on and they will create this sleeping habit, so that you can rest from this rhythm ..." (Sanchez Caro 2016) For the ECP coordinator, it is a matter of children getting used to the routine, and the job of the caregivers is to help the children acquire the habit of following a routine that points out what has to happen at each time of the day. This example highlights the idea of the global child and the developmental idea of what a child should or should not be doing at a particular time of the day. Professional practices are guided by an institutional script based on a particular notion of a child's needs that is to be followed and not by a child's needs or demands at the particular time.

The problem seems to be that the global idea of a child's daily schedule might not actually be global but rather one standpoint of what is a normal routine for a child's day. Sometimes, indigenous caregivers find themselves confirming every action with the coordinator, as they know they have to adapt and help the children to adapt, but often the daily schedule is not as evident as it might seem. In the next example, it seems that for IC1, it was not clear what they ought to do or what was considered to be a valid activity:

$\mathrm{IC} 1^{11}$ : Is it my turn to decorate everything now?

ECP: No, no, no, no. It's an activity for after lunch. (... ) for now, this (and indicates children playing "free") until all children have arrived. And then breakfast...

PEPI1: This (while looking at children)?

ECP: Yes, that (while pointing out the children playing), you play with them too ... then comes breakfast, you finish breakfast and then the cleaning. Then, you organize them at the tables, you talk to them about food, at breakfast ... you can also talk to them about food to strengthen the idea at lunch. And then on the tables, then they start (and as talking to the children) "so let's start decorating what is our dish", or as you call it. (Sanchez Caro 2016)

The ECP explains the structure of the day to the caregivers-when they are supposed to do the activities and when they can just let the children play; when they give them food and when they eat. This daily institutionalized routine, or script, must be incorporated by the caregivers, making the IC a kind of lively bridge between the scripts and the children. It sometimes seems that this everyday habit-learning-process is an important part of what the ECEC center does for this indigenous

11 For the purpose of the article and in order to guarantee anonymity, ECP is used to refer to Early Childhood Professional, IC equals Indigenous Caregivers, and children are named by a letter and their age, i.e., MP (2.11). 
community. Elias named this a "civilization process,"12 and in these cases, the focus is first on the indigenous caregivers and then passed to children. The first conclusion that can be drawn is that education seems to be for caregivers, while care and hygiene is meant to be for children. The CPI provides food and a place for children to be, whereas the discourses about childhood and education are left to caregivers, who are learning this by incorporating the script so that they can later pass it on to children.

In addition to this, the observations help gather some other characteristics of what it is to be an ECEC professional. For example, at CasaB, an IC was talking to a Taita ${ }^{13}$ from another indigenous community about the organization of daily routines and activities. Taita comes from a community-based CPI, and he argued that for them, it was important to do their own activities, like teaching children to cultivate the products. The IC was reluctant to do those activities because the children tended to start doing something else. As an example, the IC stated "We've got a cultivating space here, but the thing is kids start hitting and then you're there 'don't hit him', 'don't hit her' (Sanchez Caro 2016). This conversation happened when the children's activity was just proposed by an ECP who was following the institutional script. Paradoxically, children were running everywhere, and the professionals found themselves continuously telling children to be careful and not to hit each other. This fact was pointed out later by Taita, whom explained that at CasaC, "Children do not do activities that are not in relation to what we do/are (Sanchez Caro 2016). He indicated that the claim that the professionals in CasaB do not do specific activities like cultivating is not accurate because they encounter the same situation while doing other activities. His point is interesting-what are called "conventional" activities do not guarantee either that children will not argue or do something different than what is proposed. The argument went further; Taita asked the professionals to set up an activity of music from his community by playing to the children and making the instruments reachable to them:

Taita comes with two more drums, several drum sticks and places them on the floor in the middle of one of the pieces. MP (2.11) greets him and approaches the drum. Taita answers her greeting and says, "I'm going to play the drum. You too, but look first and don't hurt yourself." Several children now hit the drums clapping with their hands, while Taita organizes the sticks and starts playing. S (3.3) takes the flute that Taita has in her bag and goes to play with it, to the other room. Taita stays crouched down and tries several sticks on the drum and the different noises they make. An IC from an afro-descendent community tells the children, "Come and see how the drum is played." Taita plays with two different sticks, then he says "Now it's up to whom? One by one" and the children try to play like Taita did, others hit the drums differently. At some point they all start hitting at the same time. Taita tells them in a very peaceful tone "No, because you can hurt yourself. Look, look first after you do". (Sanchez Caro 2016)

This approach to children activities was also observed at CasaB when the other members of the community came to visit. In this second example, the activity was introduced to children, and it was up to them to continue the experience by themselves. This meant that children were not shown where and how to do the activity, but that it was there, available to all. That did not mean that all children participated, as there were children that stayed on the peripheral, like R (2.10), who took the drum and went away:

A Taita from their community is present and he decides to play cosecha (harvest) with the children. IC2 helps him distribute the canoes, mochilas (knitted bags), and knitted pales

12 Defined by Norbert Elias as "the social molding of individuals in accordance with the structure of civilizing process" (Elias 1994, p. 378) or a "mechanisms of integration" (Elias 1997, p. 119).

13 Respectful term to address older men which carry the wisdom of the community. 
to the children who are approaching. The children are invited to experiment with these objects. At some point, G (2.8) approaches Taita and asks him "This?" and he answers, "Yes, I will give you some. We're going to put some little grains here, aren't we?" Waiting for the little seeds, he throws a trompo (a wooden spinning top) in the middle of the room for the children to see it "dance" and he tells IC1, "Wow, how they all stay quiet to watch it (laughs)". Then he says, "Well, let's go get the seeds." IC1 goes to collect seeds from the furniture cabin and gives them to the Taita, who gets on his knees and explains to the children, "These canastos (hamper) are for the seeds. They are cultural bags of our culture. We must be able to distribute them all (while looking at the seeds)." (Sanchez Caro 2016)

These two examples underline a different script-another approach proposed by the Taitas. It seems that the way the activities were proposed here worked as a counterscript or resistance strategies. They both questioned not only the relations between children and adults but also the spaces and materiality, or Holloway and Valentin's ideas of "children's geography" (Holloway and Valentine 2004; Garnier 2014, 2015; Mannion 2007). The latter is defined as a way of thinking about adult and children interactions where mater and bodily actions on a situation matter at different levels. For this author, children's participation in a situation should be analyzed on a dialogical, spatial, and intergenerational level. Furthermore, as Wyness $(2005,2006)$ points out, these different ways of existing together questions not only the idea of "westernizing" the actions of children from other parts of the world but also the changes in professional and adult actions, as shown in this article.

Indeed, during the activity time in these three CPIs, a willingness to do "conventional" activities, or at least to follow the ECP's instructions, seemed to be a common observation. Being professional sometimes meant the IC had to organize and sit children for the activity and follow a storyboard of actions to do for them. As demonstrated in the next example, PPE1 at CasaB built a theater to explain cosecha (harvest) to children, the same activity they did with the Taita. Only this time, the children were sitting on chairs and watching the spectacle:

"For the past few minutes, the pedagogical team has been organizing and setting up an activity in the dark, with a scenario and chairs for children to seat. At the scenario, IC1 holds a white tissue and at the same time places objects between a light and the white fabric. She addresses the children: "Children, look ... its home." Then, she moves on to the second object quickly, but she is not sure she will find the result she wanted and hurries to place the other object behind the light and before the fabric and asks the children if they recognize the shapes. Immediately, she answers, "It is the children who dance because he had the cosecha. Remember that we talked about this the other day, how the children dance after the cosecha, and we danced ... well, this is the one." The other professionals are taking turns asking the children to remain seated and to stop them from approaching the light and the fabric. (Sanchez Caro 2016)

In this example, the IC was acting for the children, and it was not very clear (for her or for the children) as to how and when they could participate. It could be argued that the IC wanted to share some of her knowledge by westernizing her way of proposing activities to children. As a result, she created a mise-en-scène of cosecha, which was so far from the reach of the children that they lost their attention. By her actions, it could also be argued that the activity became unbearable for the IC. This example highlights the complexity for indigenous caregivers to follow a script that places adults in a "formative role" (Wyness 2006, 2009), as they are cornered by an institutional script that places them as a professional-in-the-making.

The fact that CasaC exists inside other's territory, or as Taita explained, they are arrinconados (cornered) inside a conventional institution, made it more difficult to tell the relation to the script. This meant that the script was to be held because they were only in the place temporarily, like guests in a host ECEC service. Most of the time, this meant that the ICs were following the scripts-waiting for the other professionals to act so they could copy their actions. In this institution, what was interesting 
were the peripheral actions of adults and children toward the daily routines. For example, TV time (which usually happened in the mornings) sometimes became knitting time for the ICs and sometimes for the indigenous children as well. For instance, F (2.6) came around the IC and held the threads of yarn so the IC could knit. There was also a building-wooden box, the only specific object to the CPI, that was at a range of use. It was easy to recognize, as throughout most of the TV time, we saw CasaC children playing around the object when they were not watching TV. Indeed, this object allowed them to come and go, to follow the script, and to get out of it in order to do some other activities.

What was interesting in this CPI was how small peripheral actions by indigenous children or adults were incorporated by the other professionals and children. They were constantly learning, more often using an indigenous baby carrier for children under one-year-old and acknowledging the value of children's participation or autonomy during lunch time: "CasaC children normally grab their plates and put them back at the service tables and get off the table when they are finished. Children from the conventional center sit at their tables and wait for teachers to bring lunch, juice and take their plates back to the service table. During the observations, we heard G (2.7) asking very loudly to one of the professionals to come and get her plate and bring her the juice. After a few minutes of running from one table to other, helping children to eat, we heard ECP reply to G 'I think you are big enough now to bring your plate and take your juice, like our friends do'"' (Sanchez Caro 2016).

\subsection{What It Is to Be Indigenous: Performing "Indigenism"14}

Following Bogota's policy text, the main purpose of the CPI as an ECEC service is to offer to groups or communities an education that "must be linked to the environment, to the productive process, to the social and cultural process, with due respect for their beliefs and traditions ( ... ) to maintain, recreate, and develop a global project of life in accordance with their own and autochthonous culture, language, traditions, and privileges" (Bogota 2010, pp. 28-29). This means that the CPI's purpose as an ECEC service in Bogotá is granted insomuch as they propose an indigenous based service. However, there is a question of what this actually means in practice. In this part, some examples of the complexity of labeling a group as indigenous in order to guarantee the particularity of the CPI are presented. Also, the experiences of children and adults are underlined.

CasaA is a CPI built on the concept of being indigenous and is owned by a private foundation. They are supervised by the Instituto Colombiano de Bienestar Familiar (ICBF), who provides them with some public financial support. Their control is defined by the professionals and the foundation manager as a "political visit", or a performance of indigenism on the day of the visit. That day, IC1 was wearing a professional outfit, not a traditional dress as expected of her, and she was questioned on it many times. One of the professionals asked her, "Have you ever worn a dress?", to which she replied that she "uses dresses, but it's not from my culture. Not this one". An ECP asked her, "Is it different? Is it from another culture? They only wear the skirt?", as she had seen on the internet (Sanchez Caro 2016).

In CasaA, the authenticity of the material space seems to take the indigenism criterion into consideration, as the space was built upon their "tradition". The foundation created a mise-en-scène of what a space for indigenous children should look like-a building wood structure that represents a maloca in order to provide early childhood services to this specific community. The day of the political visit, it was decorated with animal puppets that seemed to better illustrate what it is to be "indigenous". However, this mise-en-scène also referred to what the children and the adults should look like by questioning the IC, "What do the boys wear (while pointing to her own clothes)?" or "Do you sew them yourself (while taking the boleros from the IC3 dress)" or complimenting V (2.10) as she looked "cute"

14 The term is used following Souza Lima's definition as a set of ideas and representations regarding the relations between Indian peoples and nation states (De Souza Lima 1991, 2000), and we expand it to the larger indigenous issue, or, as Said says, "To the westerner ... the Oriental was always like some aspect of the West" (Said 2005, p. 67), so the term is particularly used to point out how indigenous are indigenized. 
in her traditional dress. Some children in the indigenous community go to conventional services at the same institution, like J (2.3) and H (2.10). Nevertheless, on the day of the political visit, all children are placed at CasaA. The professionals and the children ought to look indigenous and dress in the institutionalized version of indigenous traditional clothing. In the case of the IC, these representations do not belong to them but rather to the ECEC institution. In consequence, by being at a CPI, they also learn how to be indigenous and what that means in the institution's eyes. For example, one of the coordinators explained to the IC how to use the room that day: "They work around this table, when they go to work, they take a cushion and sit around this table, OK? And there, (while showing the books) carefully because it falls, and it's just for today" (Sanchez Caro 2016).

From how they dress to how they draw on their faces, this indigenism for the professionals and the children seems to be performance only (Butler 2011). They apparently act out their indigenism regardless of their own beliefs or images. They ought to be this indigena, authentically institutionalized. Surprisingly, during the performance, the ICs acted as the other professionals did. They acted in a formative role, telling children what and how to do things. On a daily basis, they deal with institutional planning and habitus to incorporate in relation to ECP, while children play and experience their lives on the limits of the institution. On that day, the indigenous caregivers spent more time pushing children to dance, to get dress, to be seated, and to use all sorts of objects they do not use on a daily basis:

An ECP enters the room and says, "Ready? The drum is missing," and the children repeat "music, music." IC3 takes out the drum and starts playing. IC1 organizes the children in front of the drum and tells them to dance. IC1 begins to organize the girls in line and move their arms to dance. Then, she rearranges them in a row and says, "Let's dance." He grabs T's arms and moves her, showing her how to dance. For the moment, only J and $\mathrm{H}$ are dancing. IC1 changes strategy and decides to place them in pairs and dance hand in hand: $\mathrm{V}$ and $\mathrm{H}$ and $\mathrm{T}$ and D. Now she places them in pairs to dance: A with $\mathrm{X}$ and D with T. But it doesn't work either. She decides to put $\mathrm{A}$ and $\mathrm{V}$ together, and they finally dance together, until A pushes V against the table. IC1 took V and says to her: "Pretend it doesn't hurt, and keep dancing." And they keep making children dance. (Sanchez Caro 2016)

Tension was visible in the caregivers' movements and the way they talked to each other and to children. They looked at the door, they looked at the time, and they asked other professionals if they had any updates. It was like a real play; they were behind curtains waiting for the moment to be indigenous - not as they were, but as indigenism. At that moment, it was hard to know if this was a tourism spectacle or an early childhood indigenous service. This confusion questioned the arguments behind the idea of creating the CPI and what the value was for children education. First, they were told to "pretend" to do this or that, to "pretend it doesn't hurt and dance", causing further questions about children and education and care. Surprisingly, when the visit occurred, children performed indigenism by participating and engaging in a role that demonstrated how institutionalized indigenous children should act:

The visit arrives and the ICs are asked to take care of a child falling asleep on the floor. J (2.10) improvises and says hello to the visitor and shows them her dress and dances for them. The director of the $\mathrm{CDI}^{15}$ smiles at her while the consultant moves as if she were dancing with J and says, "Let's see how you dance, show me!" In the meantime, the director of the CDI takes this opportunity to say to visitors: "Look at the books. And the plants are all about their cultivation and their things." One of the visitors asks her what she means and she replies: "Everything about them, the maloca and the animals with everything that is important to them. They all have their dresses. She is in charge (while pointing to IC1) and they are both helpers (while pointing to IC2 and IC3)"”. (Sanchez Caro 2016)

15 CDI is the term commonly used to refer to ECEC services: Centro de desarrollo integral. 
What is the pro-CPI argument? What is in it for children? It seems that learning how to be indigenous to non-indigenous eyes seems to also be a part of the institutionalized habitus to learn, as shown in this example. Even children have a role to perform because everything seems to be about this visit and they realize it, or perhaps it is just because of the performativity of the indigenous category and the fact of acting by/for this category. It raises questions of the purpose of teaching children about their culture if they are only to recreate an institutionalized idea of being indigenous-an indigenism that does not seem to be shared by the indigenous caregivers. Is this mise-en-scène also a part of the traditions that indigenous children are supposed to learn? How are they to learn to perform this indigenous category at multiple levels of discourse - those by the western institutions and those held by indigenous communities themselves?

\section{Discussion}

This analysis follows Michel Vanderbroeck's idea of a tailored service to "children from disadvantaged environments" to cover their "specific needs". Indeed, these services "present them with a mirror reflecting how society looks at them and thus how they should look at themselves, since it is only in a context of sameness and difference that identity can be constructed" (Vandenbroeck 2004, p. 109). Tailored CPIs like the ones existing in Bogotá seem to be a good way to respond to diversity and equity. Nevertheless, looking at CPIs from a wider angle brings about many questions regarding their purpose and whether there is a real need for them. As shown, many of the values and goals for this institution seem to present political, economic, and social purposes. Here, what is argued from a situated knowledge perspective is the complexity of doing differently from a very global understanding of what an ECEC service should do. Therefore, looking at the not-so well-structured CPIs in Bogotá sheds light on the process of institutionalization of CPIs and how indigenism is constructed. The main focus addresses the CPI services and their importance to the indigenous communities, and the strategies (like subtle differences) they use to hold on to what they actually want to do. During observations, some of these "subtle differences" between educational goals were noted. In the middle of an institutionalized script, which decides and "recreates" what indigenism is to be performed, little moments like "lines of flight" are examples of "subtle differences" (Deleuze and Guattari 1998). It is argued that they show counterscripts or resistance acts, which also constitutes indigenism. For example, see the importance of massage for the IC of CasaA in the next example:

IC1 starts putting all the cushions near the mattress, then brings the mattress to children's naptime, onto which they happily throw themselves. IC1 comes with an ointment, a spray for the children to massage themselves. She takes T (2.1), who lies on the mattress face down and lifts his shirt, but T doesn't want to do it. So IC1 asks who wants to participate and J (2.10) offers herself. The IC1 lifts the shirt and massages with the spray on the lower back. The other children watch and she explains, "So, caress well." Then, she lets D (2.10) massage $\mathrm{V}$ (2.10). Then, he does the same thing with $\mathrm{T}$ and $\mathrm{X}(2.9)$. V and D change, so now it's D's turn for a massage. V asks for the spray, the IC1 comes and J says in Spanish, "I'm the one massaging." Then, $\mathrm{V}$ asks for more and continues to massage D. When all the children have been "rubbed", IC1 takes the spray and puts it away in her bag. Children continue to massage their backs or rub their hands together. (Sanchez Caro 2016)

This little moment was not properly highlighted by the research at the beginning, as it seemed just another strategy to help children sleep. It was not until the post observation interviews with the professionals and the parents that the importance of the massage was realized. For adults, this practice is seen as part of their cultural knowledge given to their children at the CPI. This means they "get" the meaning and the importance of the body and herbs. Moreover, we found another subtle practice that stood out to the parents; the IC1 at CasaB, who sings to children to put them to sleep with the stories of her community, said: "I am the blood of my men and the flower of my ancestors" (Sanchez Caro 2016). 
Additionally, the IC2 at CasaC found clips of their music to play to them on TV, which meant they could also "have a moment during TV time", as explained by the professional during the interview (CasaC IC1 interview 2016).

The last census shows that while the indigenous communities in Bogota have grown, they are less than $3 \%$ of the population. During the interviews, some of the Taitas talked about their networking organization done by CPI members to "strengthen the CPI, all around the city," as Taita from CasaC said. Although Bogotá's public finances are uncertain and changeable, at a socio-political level, they have constructed their place in the ECEC system. Moreover, they have published an indigenous curriculum for early childhood education, placing their beliefs and their purpose of CPI in Bogota. They find their strength and place by helping each other and by "sharing their knowledge" from one CPI to the other. For Taita CasaC, the bigger goal is to "try to give children all these diversities, in languages, in clothes, in principles, values and habits". According to him, by working together and spending time with children in all the different CPIs, they manage to guarantee that "their own cultures and knowledge are known to the little ones" (CasaC Taita Interview 2016). This relationship between indigenous communities and different governments is part of a bigger question of how to deal with diversity and equity in our modern societies (Vandenbroeck 2004). Should we reduce children's education and care to their ethnic background, or should we ask them to attend a conventional setting and expect them to cope and to become part of what is conceived as conventional?

\section{Conclusions}

When thinking about indigenous affiliations, the notion of "edges" in Rancière (1998) helps to theorize the question of quality/diversity as a way to limit oneself in differentiating oneself. Where does the indigenous category begin and where does the children category stop? It questions different ways of being in society, such as what is it like to be a child, to be indigenous, and to be a citizen in a place where young children are cared for in Bogotá. For Rancière, the political question arises the moment we have "those who do not have the means and those who have them" (Rancière 1998, p. 37). That is where politique comes into play-"doing with the irreconcilable, with the co-presence" of the different people who are no longer outside the edges (Rancière 1998, p. 38). For him, this is the "primary task of politique", the "distribution of powers and the imaginary investments that go with it" (Rancière 1998, p. 38). However, as Ruiz (1994) states, the problem with positive discrimination policies is when they are used to "maintain the culture identity of certain minority groups", as they tend to classify them only as indigenous, for example. This might be the case for some CPIs, where they spend the day enacting authenticity or an indigenism as a means to assure their rights and protect their cultural identity. This takes us back to the beginning of the article-what cultural identity are they defending? The one institutionalized by others, as in the case of CasaA? Being indigenous becomes an enacted category that is created and creates the institutionalized indigenous child who is supposed to attend CPI services.

When Bogota's policy makers decide to take into account the ethnic criteria to supply ECEC services to young indigenous children-with the idea to give equal opportunities to actually be educated in their own cultural belongings-they also limit their access to opportunities like language exchange and others. On this note, Rancière points out that equality is a matter of standpoints. In order to argue ethnic-treatment equality, for example, we separate indigenous from the whole that is society. In doing so, inequality at some other level, such as primary school access for CPI children, will be questioned. Maybe there is a solution to the balance of equality as equity-giving to each individual what is needed to have equal opportunities.

This research is at an exploratory level, which limits the results to particular cases. For further research, there needs to be a wider angle of view built upon well-structured CPIs, such as the Muisca community in Bosa or the Misak community CPI in Engativa, in order to see how they deal with global discourses and the idea of cultural identity rights. For further research, the impact that CPIs have on children compared to conventionally educated children in their first year of primary school is also an 
interesting question. Through these analyses, whether discrimination at ECEC services actually puts CPI children at a disadvantage can be evaluated.

Funding: This research received no external funding.

Acknowledgments: Ashley Eschenburg for English proofreading and Pascale Garnier for her comments.

Conflicts of Interest: The author declares no conflict of interest.

\section{References}

Bogota. 2010. Lineamiento Pedagógico y Curricular Para La Educación Inicial. Bogota: Alcaldia Mayor de Bogota, Secretaria de Educacion de Bogota. Available online: http:/ / www.sedbogota.edu.co/archivos/Educacion_ inicial/Procesos_conjuntos/2011/Lineamiento\%20Pedagogico\%20curricular\%20educacion\%20Inicial\% 20en\%20Bogota.doc (accessed on 4 January 2019).

Boyden, Jocelyn. 1997. Childhood and the Policy Makers: A Comparative Perspective on the Globalization of Childhood. Constructing and Reconstructing Childhood: Contemporary Issues in the Sociological Study of Childhood 2: 190-229.

Brayboy, Bryan, and McK Jones. 2003. Visibility as a Trap: American Indian Representation in Schools Mahwah. In Invisible Children in the Society and Its Schools. Edited by Sue Books. New Jersey: Lawrence Erlbaum, pp. 35-52.

Butler, Judith. 2011. Gender Trouble: Feminism and the Subversion of Identity. New York: Routledge.

CasaC IC1 interview 2016. Interview Professionals CASAC, Data materials.

De Cero a Siempre. 2015. Estrategia de Atención Integral a La Primera Infancia. Comisión Intersectorial para la Atención Integral de la Primera Infancia. Bogota: Presidencia de la Républica. Available online: http:/ / www.sipi.siteal.iipe.unesco.org/sites/default/files/sipi_intervencion/estrategia_ de_cero_a_siempre._fundamentos_politicos_tecnicos_y_de_gestion.pdf (accessed on 4 January 2019).

Comisión Intersectorial de Primera Infancia. 2014. Guia 50: Modalidades y Condiciones de La Calidad Para La Educacion Inicial; Presidencia de la Republica, ICBF. Available online: https:/ / www.mineducacion.gov.co/1759/w3article-341863.html (accessed on 4 January 2019).

Comisión Intersectorial de Primera Infancia. 2014. Orientaciones Pedagógicas para la Educación inicial de niñas y niños Pertenecientes a Comunidades de Grupos étnicos; Presidencia de la república, OEI. Available online: https:/ / www.mineducacion.gov.co/1759/articles-379705_recurso_10.pdf (accessed on 4 January 2019).

Contcepi. 2012. Perfil Del Sistema Educativo Indígena Propio. Bogota: Contcepi.

Dahlberg, Gunilla, Peter Moss, and Alan R. Pence. 1999. Beyond Quality in Early Childhood Education and Care: Postmodern Perspectives. London and New York: Psychology Press.

DANE. 2007. Colombia una Nación Multicultural: su Diversidad étnica. Bogota: DANE.

DANE. 2018. Cuántos Somos? Censo 2018; Bogota: DANE. Available online: https:/ /www.dane.gov.co/index.php/ estadisticas-por-tema / demografia-y-poblacion/censo-nacional-de-poblacion-y-vivenda-2018/cuantossomos (accessed on 4 January 2019).

De Souza Lima, Antonio Carlos. 1991. On Indigenism and Nationality in Brazil. In Greg Urban E Joel Scherzer, Nation-States and Indians in Latin America. Austin: University of Texas Press, pp. 236-58.

De Souza Lima, Antonio Carlos. 2000. L'indigénisme au Brésil migration et réappropriations d'un savoir administratif. Revue de Synthèse 121: 381-410. [CrossRef]

Deleuze, Gilles. 1968. Différence et Répétition. Paris: PUF.

Deleuze, Gilles, and Felix Guattari. 1998. Mil Mesetas_Capitalismo y Esquizofrenia, 1st ed. Valencia: Pre-Textos.

Elias, Norbert. 1994. The Civilizing Process: The History of Manners and State Formation and Civilization. Translated by E. Jephcott. Oxford: Blackwell.

Elias, Norbert. 1997. La Civilisation des Moeurs. Paris: France Loisirs.

Flyvbjerg, Bent. 2006. Five Misunderstandings About Case-Study Research. Qualitative Inquiry 12: $219-45$. [CrossRef]

García Canclini, Néstor. 2004. Diferentes, Desiguales o Desconectados. Revista CIDOB D'Afers Internacionals 66-67: 113-33.

Garnier, Pascale. 2014. Childhood as a Question of Critiques and Justifications: Insights into Boltanski's Sociology. Childhood 21: 447-60. [CrossRef] 
Garnier, Pascale. 2015. Une Ville Pour Les Enfants: Entre Ségrégation, Réappropriation et Participation. Métropolitiques. Available online: http:/ / www.metropolitiques.eu/Une-ville-pour-les-enfants-entre.html (accessed on 4 January 2019).

Glazer, Nathan. 1975. Affirmative Discrimination: Ethnic Inequality and Public Policy. New York: Harvard University Press, Available online: http://www.hup.harvard.edu/catalog.php?isbn=9780674007307 (accessed on 4 January 2019).

Gomez Gomez, Mauricio Alejandro. 2015. Del chontal al ladino: Hispanización de los indios de Antioquia según la visita de Francisco de Herrera Campuzano, 1614-1616. Medellin: Fondo Editorial FCSH.

Gutierrez, Kris, Betsy Rymes, and Joanne Larson. 1995. Script, Counterscript, and Underlife in the Classroom: James Brown versus Brown v. Board of Education. Harvard Educational Review 65: 445-72. [CrossRef]

Holloway, Sarah L., and Gill Valentine. 2004. Children's Geographies and the New Social Studies of Childhood'. In Children's Geographies. Playing, Living, Learning, 2nd ed. Edited by Sarah L. Holloway and Gill Valentine. London: Routledge, pp. 1-22.

Kaomea, Julie. 2003. Reading Erasures and Making the Familiar Strange: Defamiliarizing Methods for Research in Formerly Colonized and Historically Oppressed Communities. Educational Researcher 32: 14-23. [CrossRef]

Kaomea, Julie. 2005. Reflections of an "Always Already" Failing Native Hawaiian Mother: Deconstructing Colonial Discourses on Indigenous Child-Rearing and Early Childhood Education. HÜLILI 2: 77-96.

Liebel, Manfred. 2012. Children's Rights from Below: Cross-Cultural Perspectives. Hampshire: Palgrave Macmillan.

Mannion, Greg. 2007. Going Spatial, Going Relational: Why “Listening to Children” and Children's Participation Needs Reframing. Discourse: Studies in the Cultural Politics of Education 28: 405-20. [CrossRef]

Molina, Murillo, and Diaz Baron. 2011. Lineamiento Pedagógico Para La Educación Inicial Indígena En Bogotá D.C. Alcaldia de Bogota: IDIE, OEI, SDIS.

Presidencia de la Republica. 2007. Consejo Nacional de Política Económica Social 2007. In Conpes 109 «Colombia Por La Primera Infancia»; Bogota: Presidencia de la República. Available online: https: / www.mineducacion. gov.co/1759/articles-177832_archivo_pdf_Conpes_109.pdf (accessed on 4 January 2019).

Quevedo, J. 2012. Jardines Infantiles Indígenas de Bogotá. Un Relato de La Experiencia. Bogotá: Universidad Pedagógica Nacional, Facultad de Educación, Maestría en educación.

Rancière, Jacques. 1998. Aux bords du politique. Edited by Remaniée et Augm. Paris: Folio.

Rayna, Sylvie. 2010. Quoi de neuf du côté de l'éducation préscolaire? Qualité, équité et diversité dans le préscolaire. Introduction. Revue internationale d'éducation de Sèvres, 23-30. [CrossRef]

Reyes, O. 2018. Movimientos De Re-Existencia De Los Niños Indígenas En La Ciudad. Germinaciones En Las Casas de Pensamiento Intercultural En Bogotá, Colombia. Ph.D. dissertation, Universidade Federal do Rio Grande do Sul, Porto Alegre, Brasil.

Rosemberg, Fúlvia. 2010. Tendances et tensions de l'éducation de la petite enfance au Brésil. Revue internationale d'éducation de Sèvres, 119-28. [CrossRef]

Ruiz, Miguel Alfonso. 1994. La Igualdad Como Diferenciación. In Derechos de Las Minorías y de Los Grupos Diferenciados. Madrid: Escuela Libre, pp. 283-95.

Rupin, Pablo. 2014. Participation et Apprentissages d'adultes En Milieu Préscolaire Communautaire: L'exemple Du Chili. Paris: p. 13.

Said, Edward. 2005. L'Orientalisme. L'Orient créé par l'Occident. Paris: Le Seuil.

Sanchez Caro. 2016. Observation Notes.

Sartori, Giovanni. 2005. Videopolitica: Medios, Informacion y Democracia de Sondeo. San Diego: Fondo De Cultura Economica.

SDIS. 2012. Proyecto 735: Desarrollo Integral de La Primera Infancia En Bogota; Bogota: SDIS. Available online: http: //www.integracionsocial.gov.co/index.php/noticias/35-entidad/proyectos/870-proyecto-735 (accessed on 4 January 2019).

Suárez, Iván. 2014. Sistematización de ámbitos no convencionales para la primera infancia en la localidad de los mártires. Bogota: SDIS.

CasaC Taita Interview. 2016, Interview Professionals CASAC, Data materials.

Torrado, María Cristina, Marta Torrado, María Consuelo Gaitán, and Diana Bejarano. 2017. La Política Pública Para La Primera Infancia Frente a La Desigualdad Social En Colombia. In Politicas de Infancia y Adolescencia: ¿camino a La Equidad? Edited by Ernesto Durán Strauch and María Cristina Torrado Pacheco. Bogotá: CES, pp. 87-116. 
Vandenbroeck, Michel. 2004. Diverse Aspects of Diversity: A European Perspective. International Journal for Equity and Innovation in Early Childhood 1: 27-44.

Vandenhole, Wouter. 2012. Localizing the Human Rights of Children. In Children's Rights from Below, Studies in Childhood and Youth. London: Palgrave Macmillan, pp. 80-93. [CrossRef]

Velasco, Arroyo, and Juan Carlos. 2007. Discriminación Positiva, Diversidad Cultural y Justicia. Daimon Revista Internacional de Filosofía 41: 141-56.

Wieviorka, Michel. 2004. La Discriminación Positiva. La Vanguardia, 11 November 2004.

Wyness, Michael G. 2005. Regulating Participation: The Possibilities and Limits of Children and Young People's Councils. Journal of Social Sciences 9: 7-18.

Wyness, Michael G. 2006. Children, Young People and Civic Participation: Regulation and Local Diversity. Educational Review 58: 209-18. [CrossRef]

Wyness, Michael G. 2009. Adult's Involvement in Children's Participation: Juggling Children's Places and Spaces. Children $\mathcal{E}$ Society 23: 395-406. [CrossRef]

(C) 2019 by the author. Licensee MDPI, Basel, Switzerland. This article is an open access article distributed under the terms and conditions of the Creative Commons Attribution (CC BY) license (http:// creativecommons.org/licenses/by/4.0/). 